\title{
Ethical Issues at the Beginning of Life
}

\author{
Padmaja Kanchi ${ }^{1}$, Subodh Kanchi ${ }^{2}$ \\ ${ }^{1}$ Associate Professor, Department of Community Medicine, Terna Medical College \& TSHRC, \\ Nerul \\ ${ }^{2}$ Professor \& Head, Department of Pharmacology, Vedantaa Institute of Medical Sciences, \\ Dahanu \\ Corresponding Author: Padmaja Kanchi \\ E-mail: padmamddph@gmail.com
}

Welcoming the bundle of joy is not a cakewalk for everyone. This is true, in case of, illegitimate child, foetus with congenital anomaly, twin pregnancy, seriously ill child or risk involved with mother's health. In such cases, continuation of pregnancy and welcoming the new life involves ethical dilemma.

Here, we are touching upon the ethical issues in such cases.

\section{Illegitimate Child}

Women who have given birth under such circumstances are often subjected to violence at the hands of their families; and may even become victims of so-called honour killings and may face consequent punishments, including stoning [1-2]. Teenage pregnancy is an issue and women face physical and mental trauma and huge social disastrous embarrassment in India.

\section{Serious Conditions of Foetus}

When we think in the point of view of pro-life, it is the right of an unborn child, as foetus is a human. Hence, the foetus has the rights to live. But, in case of serious conditions, like, serious congenital anomaly, twin pregnancy with one of the foetuses is dead risking the mother's life or any other medical condition affecting mother's health abortion is mandatory [3-4].

Abortion prioritizes mother's right to life and personal choices regarding her body, health and family. It also highlights the concern for the welfare of the child, concern for the life of the mother and concern for the future of the society [5].

\section{Principle of Double Effect}

Therapeutic Abortion or MTP could become unavoidable when mother's life is in danger, and this action is defended by the Principle of Double Effect.

The doctrine (or principle) of double effect is often invoked to explain the permissibility of an action that causes a serious harm, such as the death of a human being, as a side effect of promoting some good end. According to the principle of double effect, sometimes it is permissible to cause a harm as a side effect (or "double effect") of bringing about a good result even though it would not be permissible to cause such a harm as a means to bringing about the same good end [6].

For Example: In Tubal Ectopic Pregnancy, when the foetus develops in the fallopian tube instead of the uterus, mother's life would be in danger from tubal rupture as it does not support the growing foetus. Tubal rupture is a medical emergency and can cause maternal death from sudden, massive internal bleeding and the foetus will also not survive.

\section{Journey of Abortion laws in India}

August 10, 1971: The Medical Termination of Pregnancy (MTP) Act was passed which legalised abortion. 
December 18, 2002: The MTP Act was amended. The law of abortion was decentralised and penal sanctions were added for unapproved abortions that led to the formulation of MTP rules in 2003. These rules increase access for women, especially in the private health sector.

January 22, 2018: MTP Amendment Bill, 2018, was introduced in the Lok Sabha with the demand to substitute the 20 weeks duration with 24 weeks and added that it should be raised to 27 weeks in case of a rape survivor.

May 29, 2019: Petition filed at the Supreme court by Swati Agarwal, Garima Sekseria and Prachi Vats also challenged the 20 -week gestation limit saying that advancements in science and technology has made it possible to terminate pregnancies at later stages.

May 26, 2019: PIL filed by Amit Sahni in the Delhi High Court asking to raise the 20 weeks limit to 24 weeks.

August 2, 2019: Affidavit submitted by the Union Health Ministry in response to the PIL filed by Amit Sahni. The affidavit stated that draft MTP Amendment bill, 2019 has been sent for interministerial discussion.

August 6, 2019: Supreme Court issues a notice to the Centre seeking its response to the PIL filed by Swati Agarwal, Garima Sekseria and Prachi Vats [7].

\section{Ethical Concern}

Some of the ethical concerns are discussed below

\section{Can woman demand abortion as her right?}

Suitable reason and consent for medical termination of pregnancy must be documented according to the MTP Act. Only married women may use "failure of contraception" as grounds for termination of pregnancy [8].

2. Can a Doctor refuse to conduct a termination of pregnancy if it is against his conscience?

According to IMC Regulations 2002, Chapter 7.15 [9], the RMP shall not refuse on religious grounds alone, unless he feels himself incompetent to do so.

In reality, the doctor is allowed reasonable autonomy in clinical practice as MTP must take place in a hospital registered for the purpose [8].

On therapeutic abortion, the World Medical Association (WMA) acknowledges the diversity of opinion and concludes, that it is a matter of individual conviction, and conscience must be respected.

3. If mother requests MTP, can father object the procedure?

By law, the autonomy of the mother takes precedence over the father, in medical termination of pregnancy. The father cannot prevent a valid termination of pregnancy if the woman consented for it neither he can prevail on the doctor to conduct the MTP when the woman has not given the consent.

If MTP is critical for woman's health or survival, it is the doctor's duty to convince the husband and family members in the best interest of the patient.

\section{Coming to the edge}

In the past 25 years, our society has overcome longstanding taboos and repugnance to accept testtube fertilization, commercial sperm-banking, surrogate motherhood, abortion on demand within legal limit, exploitation of foetal tissue, patenting of living human tissue, ... the deliberate generation of human beings to serve as transplant donors-not to speak of massive changes in the culture regarding shame, privacy, and exposure. Perhaps more worrisome than the changes themselves is the coarsening of sensibilities and attitudes, and the irreversible effects on our imaginations and the way we conceive of ourselves. For there is a sad irony.... We expend enormous energy to preserve and prolong bodily life, but in the process, our embodied life is stripped of its gravity and much of its dignity. This is, in a word, progress as tragedy [10-11]. 


\section{Conclusion}

In the nutshell, there is plethora of complicated ethical issues when it comes to the beginning of life. A doctor has to follow his conscience and to the best interest of patient.

\section{REFERENCES}

1. Gill AK, Strange C, Roberts K. Honour killing and violence. United Kingdom: Palgrave Macmillan; 2014.

2. IMAFIDON JO. RETENTION OF DEATH PENALTY UNDER THE NIGERIAN LEGAL.

3. Birchfield L, Corsi J. The right to life is the right to food: People's Union for Civil Liberties v. Union of India \& others. Human Rights Brief 2010;17(3):3.

4. Mpinga EK, London L, Chastonay P. Health and human rights: epistemological status and perspectives of development. Med Health Care Philos 2011;14(3):237-47.

5. Beauchamp TL, Childress JF. Principles of biomedical ethics. Oxford University Press, USA; 2001.

6. McIntyre A. Doctrine of Double Effect In EN Zalta.

7. Gupta R. Abortion in India: Experts call for changes. Down To Earth [Internet]. 2019 Aug 28

8. Timms O. Bio-Medical Ethics-E-Book. Elsevier Health Sciences; 2016.

9. Jesani A. Professional codes, dual loyalties and the spotlight on corruption. Indian J Med Ethics 2014;11(3):134-6.

10. Malhotra A, Menahem S, Gillam L. Ethical issues in fetal management: a cardiac perspective. Int J Pediatr 2010;2010.

11. President's Council on Bioethics (US). Human cloning and human dignity: An ethical inquiry. President's Council on Bioethics; 2002.

$$
\begin{aligned}
& \text { Acknowledgements - Nil } \\
& \text { Source of Funding - Nil } \\
& \text { Conflict of Interest - Nil }
\end{aligned}
$$

